\title{
THE SURAKARTA MANUSCRIPT PROJECT
}

\author{
David K. Wyatt
}

University campuses characteristically are dotted with buildings bearing the names of individuals who donated the money with which they were built, or who were otherwise benefactors of the university. A century hence, some might conclude that the John M. Echols Collection on Southeast Asia in the Cornell University Libraries commemorates some wealthy giant of industry, like the John M. Olin Library in which it is housed. John Echols was indeed a "giant of industry, " but in a sense quite different from that in which the phrase usually is used. The Echols Collection is a rare example of a university facility named after one whose contribution was in the form of time, labor, intellect, and love of books. John Echols' more than twenty years of patient industry has been the key element in making the Echols Collection such an extraordinarily good library for the study of Southeast Asia.

Both the Collection's excellence and John Echols' infectious bibliographic fervor (some would say "passion") have inspired many of the Collection's users to follow John's example and join in the effort to make it even better, to fill in the gaps in its holdings, and pursue that ever-elusive goal of building a library where scholarship need never halt for a missing source. John was ever ready to encourage them, always generous with advice, and the first to acknowledge and thank them. He took special interest in promoting the microfilming in Southeast Asia of materials in danger of disintegration, thus safeguarding them not only to facilitate foreign scholarship but also to ensure their preservation for Southeast Asian generations to come.

Four years ago, Nancy Florida, a graduate student in Southeast Asian history at Cornell, came to me, to John Echols, and to Oey Giok Po, curator of the Echols Collection, with a letter from K. R. M. T. Sanjoto Sutopo Kusumohatmodjo, curator of the Rekso Pustoko at the Mangkunegaran in Surakarta, inquiring whether Cornell might be able to assist in getting the Javanese manuscripts in his charge microfilmed, in order to protect them from further deterioration and from potential damage from flood or fire. After exploring various local possibilities, John Echols and the Library encouraged Florida and me to submit a grant application to the National Endowment for the Humanities, under their Research Materials Program. The NEH awarded the sum of $\$ 42,068$ to the Surakarta Manuscript Project in May 1980 to cover six months' microfilming of Javanese-language manuscripts at the Mangkunegaran, followed by thirty months of postfield processing and cataloguing.

Two years later, there is very little resemblance between the original proposal submitted to the National Endowment in 1979 and the actual work that has since been accomplished. Quite apart from incessant and considerable technical difficulties, and from the complications of administering a project over a distance of twelve thousand miles, the scope of the project itself dramatically changed. The project field team, comprised of Nancy Florida as head and cataloguer, and Alan $\mathrm{H}$. Feinstein as camera operator, began operations in Surakarta in August 1980. Within a few months, they were approached by those in charge of two additional major depositories--K. G. P. H. Praboewidjojo (Pangageng Parentah Karaton Surakarta) and 
K. R. T. Hardjonagoro (Kepala Paheman Radya Pustaka)--who invited the project to extend its microfilming operations to include their extensive and important holdings. What began as a six-month project then turned into more than two years of microfilming, and to a projected final total of 250 reels of microfilm encompassing nearly 2,000 volumes and almost 600,000 pages of Javanese manuscripts.

From the beginning, we decided to film absolutely everything, no matter how apparently insignificant or reduplicative. Moreover, Nancy Florida provided every item filmed with a microfilm target sheet giving extensive, detailed information concerning the manuscript. Under terms Nancy Florida and James $T$. Siegel negotiated with the individual depositories and the Indonesian Department of Education and Culture, negative copies of the microfilms are deposited at the National Archives in Jakarta and at Cornell, while the originating depositories and Cornell both maintain positive copies available for scholarly use. The microfilms can be copied only with the consent of the originating depository, and their use is restricted to scholarly and research purposes.

The bulk of the microfilms was turned over the Cornell University Libraries in April 1982, with additional reels added as they arrived from Java. They are now becoming available for use. The purpose of this note is to make their existence known, and to explain how they might be used during the transitional period before they have been fully catalogued.

At present, the Surakarta manuscripts run to 242 reels of microfilm. Of these, 190 reels were shot on $35 \mathrm{~mm}$. film and 52 reels on $16 \mathrm{~mm}$. film. The latter are somewhat less convenient to read, having been exposed at a reduction ratio of $29: 1$, rather than the $12: 1$ or $16: 1$ of the $35 \mathrm{~mm}$. films; and they require the use of a more powerful microfilm reader.

Of the first 230 reels of film received, 105 were filmed at the Mangkunegaran, 49 at the Museum Radya Pustaka, and 76 at the Karaton Surakarta. The filmed manuscripts may be described under four broad categories. First, the largest category, incorporating roughly 60 percent of the total material, can generally be described as Javanese literature. This is, however, a highly diverse category. In addition to the classical epics and romances, it includes a great deal of Ronggawarsita's prodigious writings, mythic histories of archaic Java, moralistic and didactic works, prophetic and messianic writings in both the Hindu-Javanese and Islamic traditions, collections of short occasional poems, and writings on the Javanese language and script. Second, approximately 28 percent of the total falls generally into the category of "history." In addition to a superb collection of babad chronicles, this category ranges from the annals of medieval Mataram and its contemporaries to registers of events as late as the attainment of Indonesian independence from the Netherlands. There are extensive collections of documents, including correspondence with the Dutch colonial regime, and court genealogies and records of events and royal journeys. Third, about 6 percent of the total collection is comprised of works relating to the Javanese court and its administration in the nineteenth and twentieth centuries. Included here are handbooks of ceremonies and of court etiquette, works on Javanese ranks and titles, and records of the court and land administration. Fourth, a final 6 percent of the manuscripts can be described as dealing with Javanese traditions and lore. This category includes works on keris-and iron-working, on indigenous architecture, on the gamelan and music, and on manners and customs in general.

A collection so extraordinarily rich is not readily susceptible to conventional library cataloguing. The Cornell University Libraries have chosen to enter it in the computerized "card" catalogue under a single general entry, and to refer the user to two temporary finding aids, neither of which is indexed. The first, 
"Javanese-Language Manuscripts of Surakarta, Central Java: A Preliminary Checklist, $"{ }^{1}$ is a 55-page, single-spaced listing of all titles filmed, in the order of their filming, with cross references to each manuscript's catalogue number in the originating depository and to its Surakarta Manuscript Project (SMP) catalogue number. The second finding aid, "Javanese-Language Manuscripts of Surakarta, Central Java: A Preliminary Descriptive Catalogue, " 2 is a massive, four-volume, 2,000-page collation of the target sheets filmed with each individual manuscript. This is organized by SMP catalogue number within three groups, one for each of the originating depositories. Within each group, titles are arranged in general subject categories, so that, for example, most of the materials on history in each depository appear together. At the top of each page is written the number of the microfilm reel in which that item is filmed.

When all filming has been completed, we will be in a position to compile and publish a final catalogue of the entire collection. In addition to presenting all the material included on Florida's target sheets--author, title, original depository and manuscript catalogue number, date and place of writing, copyist, date and place of copy, number and size of pages, brief description of contents, and pertinent notes (including references to other copies of the same manuscript, e.g., from Pigeaud's Literature of Java)--this catalogue will include extensive indexes and cross references.

Pending the completion of the published catalogue, it should be useful here to provide those interested with a few short samples of the materials included in this extensive collection. From the enormous riches of the collection, we have chosen to show some of the historical chronicles appearing there, and reproduce below the lists of babad titles on reels 90-93 and 96-105 (from the Karaton Surakarta), reels 47-61 (from the Mangkunegaran), and reels 82-84 and 86 (35 mm.) and 16/20A-16/24 (16 mm.) (from the Radya Pustaka). Babad constitute only a small proportion of the historical literature included in the collection; and these selections do not begin to suggest the enormous range of cultural and literary texts the microfilms encompass; but they may give at least some indication of the depth within a single category.

Scattered throughout Nancy Florida's "Preliminary Descriptive Catalogue" are such comments as "MS. severely damaged from insect infestation," "Leaves of MS. are very brittle; many leaves were in fragments which were re-pieced for filming. Legibility impaired by severe ink bleed-through," "Further volumes are apparently no longer extant," "MS . is in deplorable condition," and "Some leaves of MS . are water-damaged." Despite the considerable efforts of their curators in Surakarta, handwritten manuscripts cannot last forever. They have proven vulnerable to insects, to the climate, and to flood; and even within the past year an electrical fire in the Karaton Surakarta came dangerously close to the library. Thanks to the foresight of those responsible for the Surakarta depositories, combined with the herculean efforts of Nancy Florida and the field team and the support of Professor Siegel, these three important Surakarta collections now have been microfilmed. With the deposit of copies of the microfilms in Jakarta and Ithaca, there now is immeasurably less chance of the irrevocable loss of any of these treasures of the Javanese heritage.

1. Xerox copies of this typed listing are lodged with the microfilms, and can be obtained by writing to me at Cornell.

2. This catalogue is not available except in the depositories. 
Excerpts from "Javanese-Language Manuscripts of Surakarta, Central Java: A Preliminary Checklist"* (January 1982)

by

Nancy K. Florida

Key to Abbreviations

$\begin{array}{ll}\text { Surakarta Manuscript Project } & \text { SMP } \\ \text { Karaton Surakarta } & =\mathrm{KS} \\ \text { Mangkunegaran } & =\mathrm{MN} \\ \text { Museum Radya Pustaka } & =\mathrm{RP} \\ \text { Catalogue number in originating depository } & =\mathrm{Cat} \text {. no. }\end{array}$

Karaton Surakarta

(35 mm.)

Reel no. 90

SMP no. $K S /-\quad$ Title

19 serat Babad Caluh.

21 serat Babad Pajajaran.

22 serat Babad Pajajaran (SMP/SP 22)

23 Babad Pajajaran.

24 Babad Pajajaran.

28 serat Walisana.

30 Babad Mataram.

\begin{tabular}{ll} 
Cat. no. & \multicolumn{1}{c}{ Pages } \\
$272 \mathrm{na}$ & 250 \\
190na & ii, 568 \\
$200 \mathrm{na}$ & $\mathrm{i}, 474$ \\
$28 \mathrm{ca}$ & 152 \\
$182 \mathrm{ca}$ & $\mathrm{i}, 451$ \\
$11 \mathrm{ca}$ & $169, \mathrm{vii}$ \\
$194 \mathrm{na}$ & $\mathrm{i}, 22$
\end{tabular}

Reel no. 91

25 serat Babat Pajajaran dumugi Mataram 200na

29 serat Babad Baron Sakendher. 173na

31 serat Babad Pajang. 271na

32 serat Babat Mataram. 180ca

27B serat Sujana. 92na

Reel no. 92

25A Babat Majapahit wekasan dumugi Mataram. 554ra iii, 925

33 Babat Mataram. 127na $\quad$ ii, 276

34 Babat Mataram. $180 \mathrm{ca} \quad$ i, 328

35 Babat Mataram (SMP/SP 35). 158na i, 302

36 Babat Mataram (SMP/SP 36). 158na [sic] ; i, 393

(Continued on Reel no. 93) 108na

Reel no. 93

36 Babat Mataram (continued). 158na

37 Babat Mataram. 224na i, 547

* Titles are exact transcriptions of the Javanese orthography; the irregularities reflect the usual variability of spelling prior to standardization in print. 


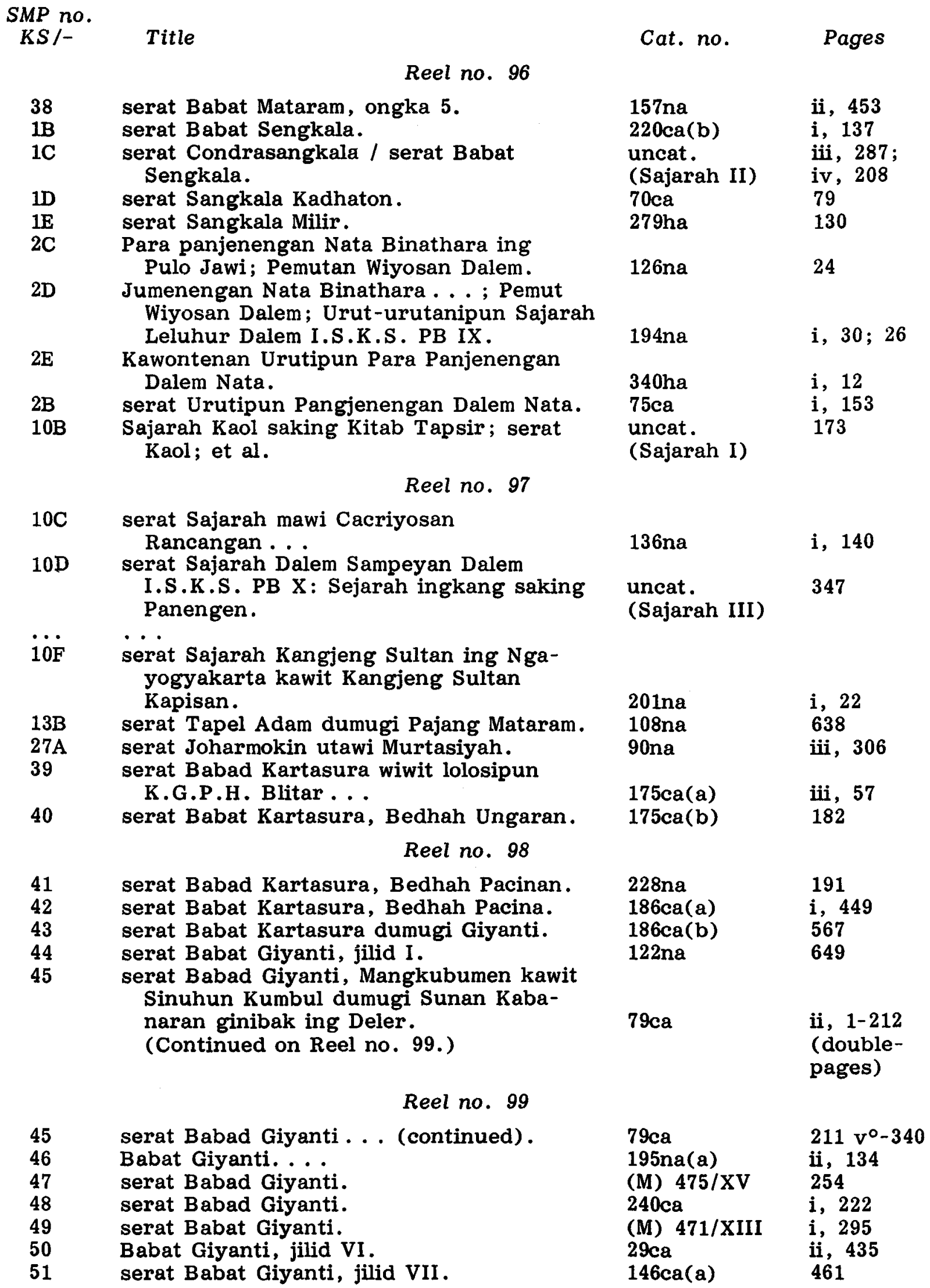




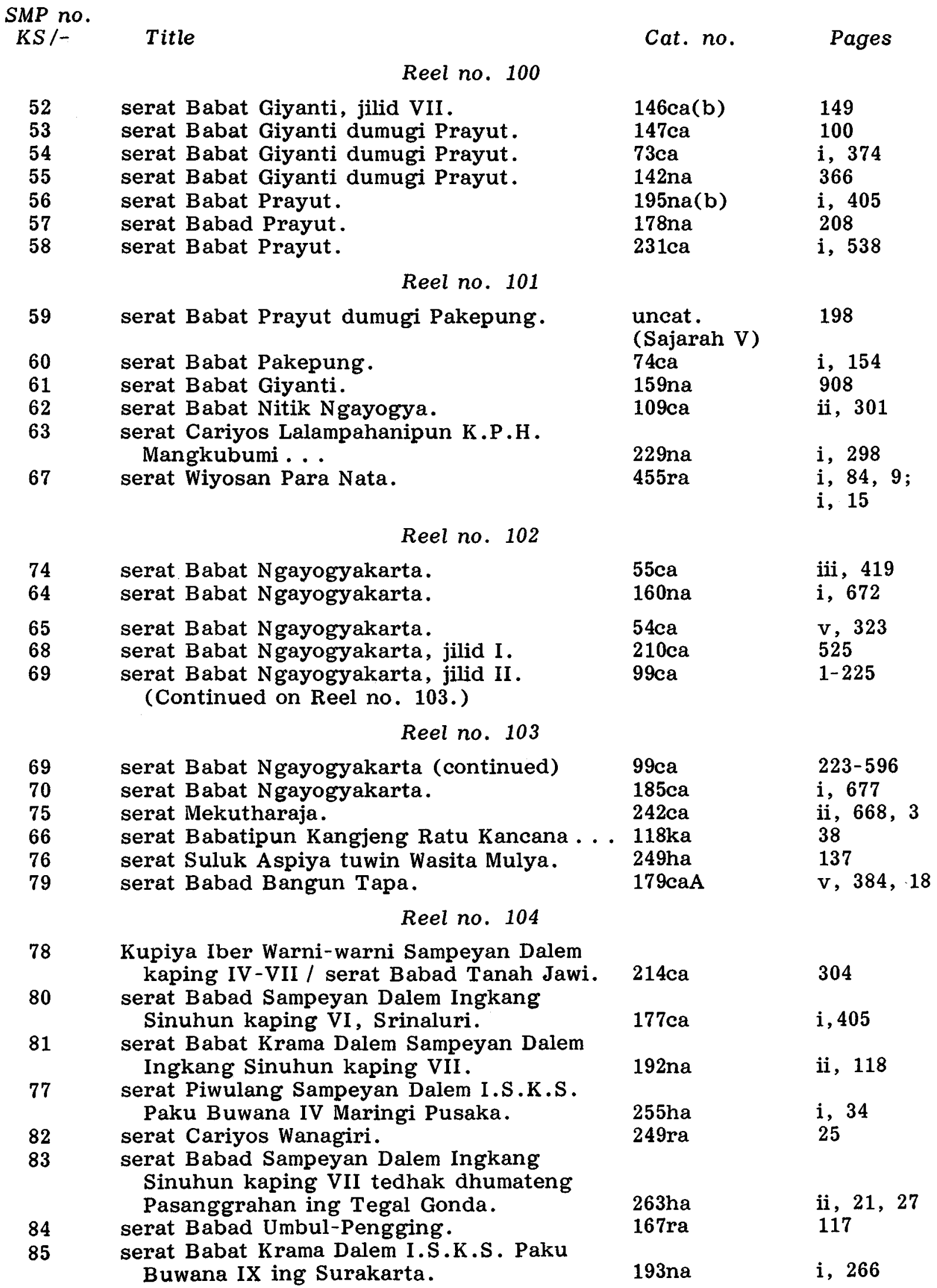


$S M P$ no
$K S /-$

\section{6}

87

87

88

90

91

91

92

93

94

95

96

97

98

99

89

100

101

102

103

104

105

106

107

108

109

110

111

112

\section{Title}

Sajarah Dalem I.S.K.S. Paku Buwana IX wiwit Putra Dalem . . . serat Babad Langenarja, jilid II-VIII .

(Continued on Reel no. 105.)

Reel no. 105
Cat. no.

Pages

$117 \mathrm{ca}$

253ha

74

$1-727$

253ha

$187 \mathrm{ra}$

391ha

262ha

serat Langenarja, V. XXI.

serat Babad Langenarja, jilid XXII.

(Continued on Reel no. 106.)

Reel no. 106

serat Babad Langenarja, jilid XXII

(continued).

serat Babad Langenarja, jilid XXIII.

serat Babad Langenarja, jilid XXIV.

serat Babad Langenarja, jilid XXV.

serat Babad Langenarja, jilid XXVI.

serat Babad Langenarja, jilid XXVII.

serat Babad Langenarja, jilid XXVIII.

serat Babad Langenarja, jilid XXIX.

serat Babad Langenarja, jilid XXX.

serat Babad Langenarja, jilid XIX.

serat Babad Langenarja, jilid II.

serat Babad Langenarja, jilid III.

serat Dombasawala.

serat Dombasawala.

serat Anyariyosaken Pasamuwan Supit

Dalem K.G.P.A.A. Amangkunagara V.

serat Babat Tedhak Dalem ing Langenarja.

serat Nata Cangkrama.

serat Babad Surut Dalem Kangjeng Ratu

Ageng.

serat Saosan Ranupranatan.

serat Babon Babat Baita Kiyahi Rajamala.

serat Babatipun Kagungan Dalem Baita

Kiyahi Rajamala.

Ngengreng serat Babat Surakarta, ongka III.

Ngengreng serat Babat Surakarta, ongka IV.

(Continued on Reel no. 108.)

$726-1130$

1489

$i, 233$

i, $1-115$
Reel no. 107

262ha

313 ha

294ha

241ra

$392 \mathrm{ra}$

29ha

295ha

296ha

297ha

390ha

114- 208

i, 258

i, 238

i, 268

i, 268

i, 203

203

201

i, 213

241

180na

$219 \mathrm{ca}$

$89 \mathrm{ra}$

146na

336ha

68ha

264ha

618ha

285ra

357ra

$357 \mathrm{ca}$

$5 \mathrm{ca}$

$30 \mathrm{ca}$

Reel no. 108 i, 268

i, 218

i, 137

231

22

i, 68

ii, 86

18

55

89

ii, 434

ii, 1-242
124,3

112 Ngengreng serat Babat Surakarta, ongka IV (continued).

$30 \mathrm{ca}$

241-278

113

Ngengreng serat Babat Surakarta, ongka $\mathrm{V}$.

114 Ngengreng serat Babat Surakarta, ongka VI.

$4 \mathrm{ca}$

i, 380

154na

i, 132 
SMP no. $K S /-$ Title

Cat. no.

$114 \mathrm{ca}$

i, 324

$116 \quad$ Ngengreng serat Babat Pemut ing Nagari Surakarta, ongka VIII.

$117 \quad$ Ngengreng serat Babat Pemut ing Nagari Surakarta, ongka IX.

118 Ngengreng serat Babat Pemut ing Nagari Surakarta, ongka X.

Reel no. 109

119 Ngengreng serat Babat Pemut ing Nagari Surakarta, ongka XI.

120

121

122

123

124

125

126

127

128

129

130

-..

serat Babat Pemut ing Nagari Surakarta, ongka XII.

serat Babat Pemut ing Nagari Surakarta, ongka XIII.

serat Babat Pemut ing Nagari Surakarta, ongka XIV.

Cariyos Bena Surakarta / serat Tedhak Dalem I.S.K.S. Paku Buwana X dhumateng Pasanggrahan Dalem 'Tegal Gonda. Buk Pemutan Kawit 26 Besar Ehe 1820 dumugi 12 Siyam Je 1822.

$20 \mathrm{ca}$

i, 430

$31 \mathrm{ca}$

i, 393

6ca

ii, 358

Buk Serat dhumateng ing Prangwadanan.

Lepiyan serat Dhawuh . . . PB X.

Buk Dhawuh dhumateng ing Kapatiyan.

Buk Dhawuh dhumateng ing Sujanapuran.

Buk Dhawuh dhumateng ing Sujanapuran.

Buk Dhawuh dhateng ing Prabuwijayan.

$155 \mathrm{na}$

i, 322

52ca

i, 297

$32 \mathrm{ca}$

i, 276

33ca

ii, 296

$64 c a$

$87 \mathrm{ca}$

126

$86 \mathrm{ca}$

8

$217 \mathrm{ca}$

287

$105 \mathrm{ca}$

$81 \mathrm{ca}(\mathrm{A})$

i, 18

i, 59

$80 \mathrm{ca}$

30

$67 \mathrm{ca}$

i, 41

i, 16,53

\section{Mangkunegaran \\ ( $35 \mathrm{~mm}$.)}

Reel no. 47

$M N /-$

...

172

173

173

174

175

176

177

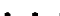

serat Babad Mataram, jilid II. serat Babad Mataram, jilid III .

(Continued on Reel no. 48.)

Reel no. 48

serat Babad Mataram, jilid III (continued). serat Babad Mataram, jilid IV. serat Babad Mataram, jilid V ("serat

Babad Kartasura").

serat Babad Mataram, jilid VI.

B $-10 \mathrm{i}$

B $-10 e$

ii , 299

i, $1-330$

$\begin{array}{ll}\text { B-10e } & 329-570 \\ \text { B-10g } & \text { i, } 586 \\ \text { B-21f } & \text { i, } 613 \\ \text { B-32c } & \text { i, } 636\end{array}$

Reel no. 49

serat Babad Mataram, jilid VIII ("serat Babad Kartasura").

$B-21 h$

589

...

180 serat Ajisaka Ngejawi.

B $-4 a$

i, 418 


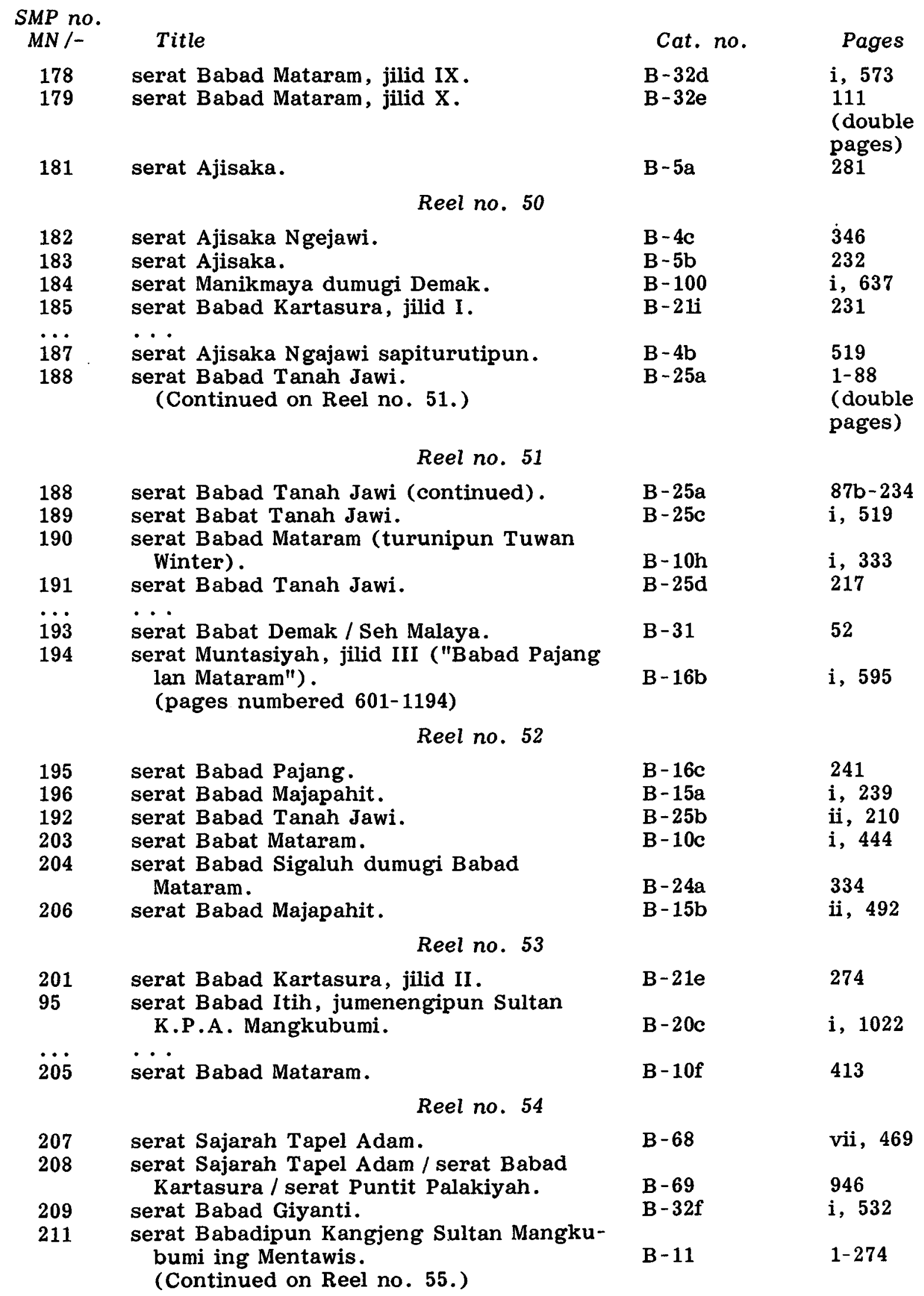


SMP no.

$M N /-$

Title

Cat. no.

Pages

Reel no. 55

211 serat Babadipun Kangjeng Sultan Mangkubumi (continued).

216 serat Cabolek.

217 serat Babad Giyanti.

218 serat Babadipun Kangjeng Pangeran

Dipanagara.

219

198

serat Babad Madura.

serat Babad Mataram.

(Continued on Reel no. 56.)

$\begin{array}{ll}\text { B-11 } & 273-395 \\ \text { O-7 } & \text { ii, } 242 \\ \text { B-10d(b) } & 670 \\ & \\ \text { B-12 } & \text { i, } 297 \\ \text { B-13 } & 252 \\ \text { B-10d } & 1-552\end{array}$

Reel no. 56

198

200

222

223

224

225

226

227

229

230

230

$228 \mathrm{a}$

$228 \mathrm{~b}$

232

233

234

235

236

237 serat Babad Mataram (continued).

serat Babad Kartasura.

serat Babad Panambangan, jilid I.

serat Babad Panambangan, jilid II.

serat Sajarah kanthi Babad Lalampahanipun

K.G.P.A.A. Mangkunagara IV.

serat Sajarah Ki Ageng Tarub dumugi

K.G.P.A.A. Mangkunagara IV .

serat Pakem Aluraning Leluhur Mangkunagara III tuwin IV.

serat Pemutan Lalampahan K.G.P.A.A.

Mangkunagara $\mathrm{V}$.

serat Babad Dalem K.G.P.A.A. Prabu

Prangwadana VII.

serat Babad Dalem K.G.P.A.A. Prabu

Prangwadana VII, lajeng jumeneng

K.G.P.A.A. Mangkunagara VII .

(Continued on Reel no. 57.)

Reel no. 57

serat Babad Dalem K.G.P.A.A. Prangwadana VII (continued).

Krama Dalem Prangwadana.

serat Babat Pawiwahanipun K.G.P.A.A.

Prabu Prangwadana V.

serat Sarasilahipun para putra dalem

K.G.P.A.A. Mangkunagara VII.

serat Pemut Wiyosanipun para putra

dalem ... Mangkunagara VII.

serat Babat Wanagiri.

serat Babad Nyanjata dhateng ing Wanagiri ing tahun 1808.

serat Register Isi Pengetan sadaya rembagrembag, lampah-lampah tuwin waragadipun krama dalem K.G.P.A.A. Prabu Prangwadana VII. (Refilmed on Reel no. 16/41.)

Buku Register Pranatan Pasamuwan tuwin sanes ${ }^{2}$-ipun kangge Kantor Reksa Pustaka.

\begin{tabular}{|c|c|}
\hline $\begin{array}{l}B-10 d \\
B-21 c \\
B-18 a \\
B-18 b\end{array}$ & $\begin{array}{l}551-582 \\
342 \\
\text { ii, } 178 \\
\text { iii, } 112\end{array}$ \\
\hline$B-66$ & iv, 178 \\
\hline$B-38$ & $i, 83$ \\
\hline$B-103$ & 11 \\
\hline B -74 & $i, 19$ \\
\hline$B-27$ & ii, 332,19 \\
\hline B - 14 & iv, $1-597$ \\
\hline $\begin{array}{l}B-14 \\
H-11\end{array}$ & $\begin{array}{l}596-908 \\
60\end{array}$ \\
\hline$B-46$ & 46 \\
\hline$B-67$ & 18 \\
\hline $\begin{array}{l}B-33 \\
B-58\end{array}$ & $\begin{array}{l}41 \\
20\end{array}$ \\
\hline$B-57 b$ & 27 \\
\hline $\mathrm{H}-10$ & i, 30 \\
\hline $\mathrm{H}-12$ & $i, 257,6$ \\
\hline
\end{tabular}




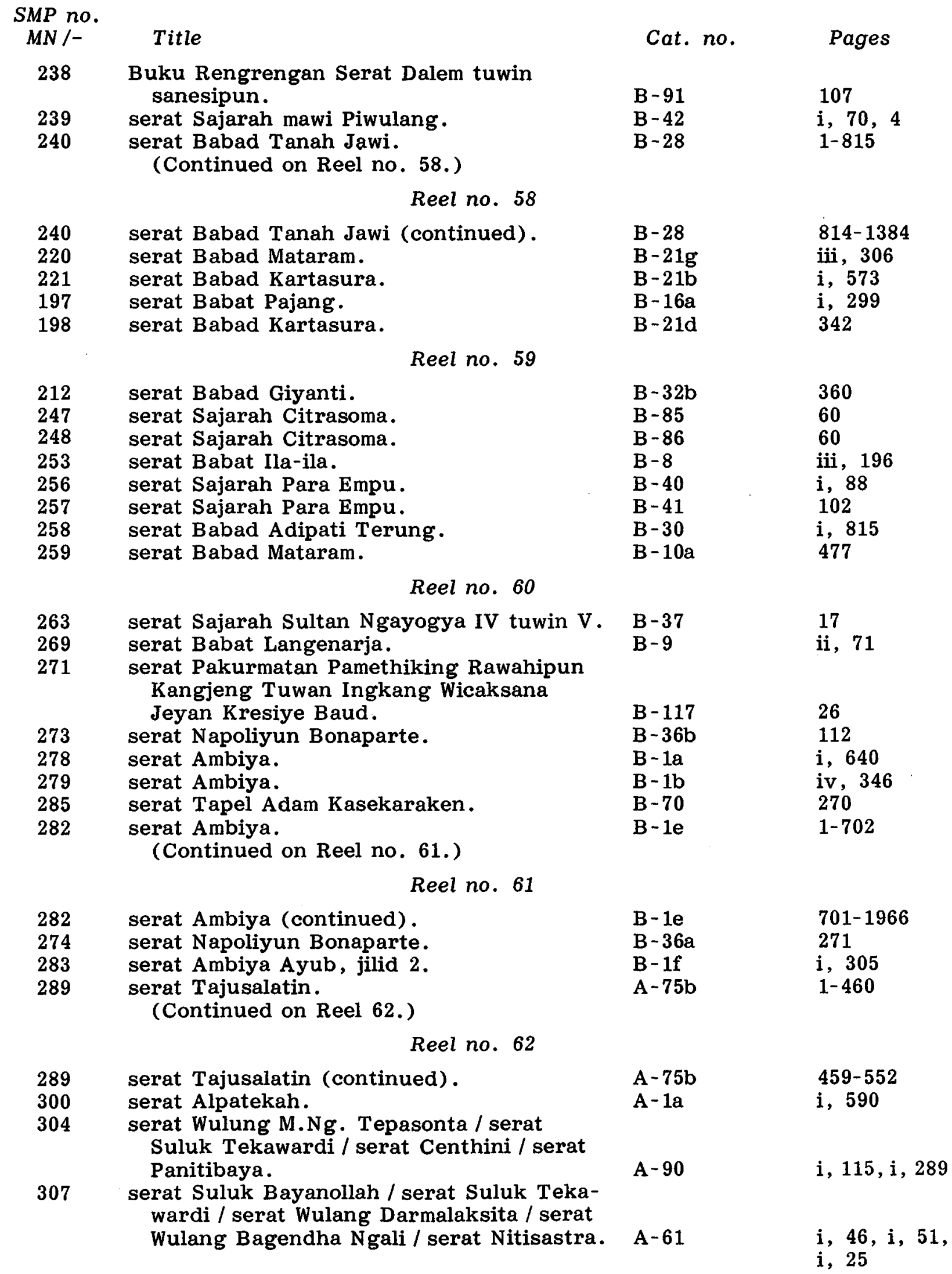


SMP no $M N /-$

Title

Cat. no.

Pages

308

serat Pambukaning Ngelmi Gaib.

A -63

A-3

i, 144

serat Asmarasupi.

serat Tajusalatin / serat Jayalengkara

Pamriyan.

(Continued on Reel no. 63.)

A $-75 e$

i, 247

294

Reel no. 63

294 serat Tajusalatin / serat Jayalengkara

Pamriyan (continued).

A $-75 e$

A -62

$155 b-398$

suluk Nakim / serat Wulang Dalem PB IX.

A-78

70

318 Buku Kagungan Dalem Wirid Girijaya.

306 serat Suluk Purwadaksina / serat

Tekawardi.

A-85

B-22

A-79

$1-155 b$

serat Babad Pacina.

319 serat Wirid Hidayat Jati.

i, 148,2 ;

vii, 124

Museum Radya Pustaka

(35 mm.)

Reel no. 82

$R P /-$

5 serat Ambiya.

7 serat Manikmaya.

32 Babad Kartasura dumugi Giyanti.

(Continued on Reel no. 83.)

257a carikan

$244 \mathrm{ca}$

$114 \mathrm{ca}$

Reel no. 83

Babad Kartasura ... (continued). serat Babad Giyanti dumugi Prayut. Babad Giyanti dumugi Prayut.

(Continued on Reel no. 84.)

Reel no. 84

Babad Giyanti ... (continued). serat Babad Ngayogyakarta. Ngengreng serat Babad Surakarta, I, II , III

Reel no. 86

Babat Ngayogya Geger Sepehi. serat Sejarah Urun Wijining Kraton. serat Sejarah Urun Wijining Kraton. serat Sejarah Urun Wijining Kraton. serat Sejarah. serat Poncaniti / serat Tajusalatin / Bausastra Kawi.
312 ca

$117 \mathrm{ca}$

114 ca

$291 \mathrm{ca}$

$312 \mathrm{ca}$

$131 \mathrm{ca}$

317 ca

$316 \mathrm{ca}$

$83 \mathrm{~b} \mathrm{ca}$

$83 \mathrm{a} \mathrm{ca}$

$86 \mathrm{ca}$

$78 \mathrm{ca}$

253 ca i, 808

ii, 273

ii, $1-428$

75 (double-

464

82
429- 493

ii, 562

i, 1-437
$436-512$

i, 654

iii, 869

645

i, 728

iii, 64

i, 50

i, 87

134

xliii, 957 


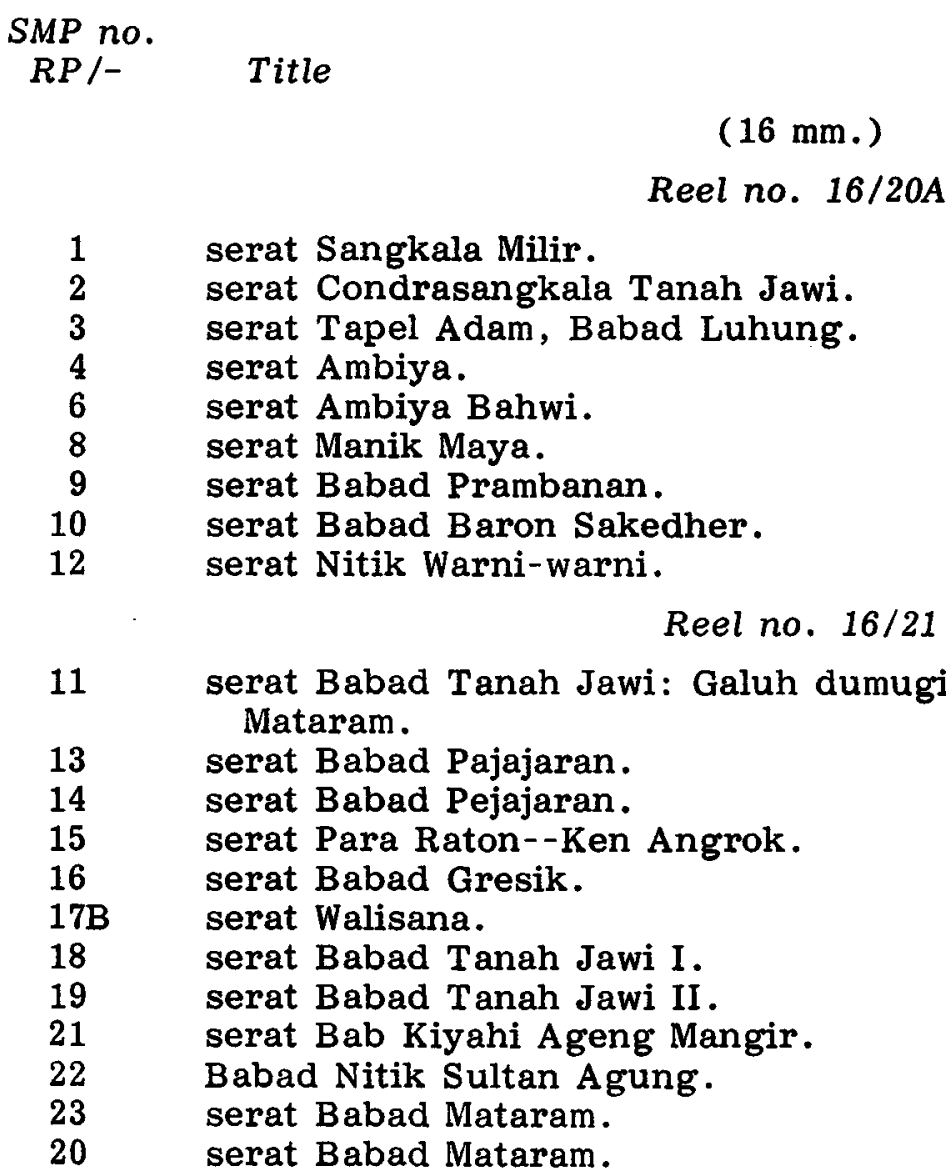

Reel no. 16/21

Reel no. 16/22

serat Babad Mataram; serat Babad

Pakunagaran.

serat Babad Kartasura.

serat Babad Kartasura I.

serat Babad Kartasura II.

serat Babad Kartasura III.

serat Babad Kartasura IV.

serat Babad Kartasura.

Reel no. $16 / 23$

serat Babad Tanah Jawi.

serat Babad Kartasura Bibar Pacina dumugi

Surakarta Jumenengipun Ingkang Sinuhun

Paku Buwana Kaping III.

serat Babad Giyanti.

serat Babad Giyanti.

serat Babad Nomer 8, Awit Prang

Pajenar.

Reel no. $16 / 24$

serat Babad Giyanti dumugi Prayut. serat Babad Prayut (serat Babad
Cat. no.

Pages
342

iv, 135

ii, 177

497

i, 178

400

236

i, 207

iii, 191

$\begin{aligned} 115 \text { (Carikan) } & \text { viii, } 573 \\ 140 \text { (Carikan) } & 228 \\ 118 \text { (Carikan) } & 174 \\ 80 \text { (Carikan) } & i, 38 \\ 137 \text { (Carikan) } & 66 \\ 160 \text { (Carikan) } & 232 \\ 124 a \text { (Carikan) } & 188 \\ 124 b \text { (Carikan) } & 190 \\ 358 \text { (Carikan) } & \text { i, 33 } \\ 139 \text { (Carikan) } & 92 \\ 285 \text { (Carikan) } & 678 \\ 123 \text { (Carikan) } & \text { i, } 265\end{aligned}$

146 (Carikan)

127 (Carikan)

120 (Carikan)

122 (Carikan)

121 (Carikan)

129 (Carikan)

288 (Carikan)
197,252

i, 344

iii, 286

i, 134

i, 265

ii, 517

iii, 442

1 (Carikan) iv, 341

128 (Carikan)

iv, 473

130 (Carikan)

394,3

99 (Carikan) i, vi, 284

133 (Carikan) i, 469

Giyanti Ongka IX).

308 (Carikan) i, 8, 237

134 (Carikan) 175 
SMP no. $R P /-$

Title

Cat. no.

Pages

39

serat Babad Giyanti dumugi Prayut.

116b (Carikan)

ii, 623

Giyanti Ongka X).

$116 a$ (Carikan) iv, 490

45 serat Babad Ngayogya Sultan Mangkubumi Sampun Jumeneng Ngayogya Nomer I.

46 serat Babad Ngayogya Sultan Mangkubumi Sampun Jumeneng N gayogya Nomer II.

132a (Carikan) ii, 207

47 serat Babad Ngayogya Sultan Mangkubumi

132b (Carikan) ii, 254 Sampun Jumeneng Ngayogya Nomer III.

132c (Carikan)

i, 238 